\title{
PERSEPSI MAHASISWA TENTANG POSISI STRATEGIS PROFESI PUBLIC RELATIONS
}

\author{
Trie Damayanti, Susie Perbawasari \\ Departemen Ilmu Hubungan Masyarakat, Fakultas Ilmu Komunikasi, Universitas Padjadjaran
}

\begin{abstract}
ABSTRAK
Penelitian berjudul Persepsi Mahasiswa Tentang Posisi Strategis Profesi Public Relations ini bertujuan untuk mengetahui (a) Bagaimana mahasiswa Jurusan Humas memaknai posisi strategis Profesi PR dalam organisasinya, (b) Bagaimana mahasiswa Jurusan Humas memandang dan memaknai Ilmu Kehumasan yang dimiliki untuk diterapkan pada Profesi PR, (c) Bagaimana mahasiswa Jurusan Humas memandang dan memaknai kemampuan yang harus dimiliki oleh seorang PRO. Penelitian ini menggunakan metode kualitatif dengan pendekatan fenomenologis, dengan perspektif teoretis konstruksi sosial atas realitas.Nara sumber diambil dari mahasiswa Jurusan Humas semester III, V, dan VII sebanyak enam orang. Penentuan sampel dilakukan secara purposif. Hasil penelitian menun- jukkan bahwa (1) mahasiswa memaknai posisi strategis PR dilihat dari kedekatannya dengan pengambil kebijakan seperti realitas yang memang beredar di masyarakat bahwa semakin dekat seseorang dengan pimpinan akan semakin strategis posisi tersebut; (2) mahasiswa memandang dan memaknai Ilmu Kehumasan yang dimiliki sesuai dengan materi perkuliahan yang pernah didapat dan realitas yang berkembang di masyarakat tentang profesi ke-PRan. Ilmu Kehumasan lebih dilihat dari materi yang membutuhkan skill dan materi yang aplikatif; (3) mahasiswa memandang dan memaknai kemampuan yang harus dimiliki pada hal yang berkaitan dengan materi perkuliahan ditambah dengan bahasa asing, dan komputer seperti halnya realitas yang memandang kemampuan komputer dan penguasaan bahasa asing menjadi hal yang membuat orang dipandang lebih kompeten dibandingkan yang lain. Kesimpulan didapat bahwa pandangan mahasiswa terhadap posisi strategis Ilmu Kehumasan yang akan diterapkan, sampai dengan kemampuan yang harus dimiliki oleh seorang PRO sangat dipengaruhi oleh realitas dan pengetahuan sebelumnya pada pemahaman tentang strategi, pemaknaan pada Ilmu Kehumasan juga dipengaruhi pada pengalaman mereka pada Ilmu Kehumasan dan pengetahuan yang berkembang sebelum mereka menjadi mahasiswa. Saran yang bisa diberikan terutama dalam hal pemberian pemaknaan tentang Public Relations, sebaiknya diperkaya juga tentang PR pemerintah karena terbukti minim sekali pemahaman mahasiswa pada PR di pemerintahan.
\end{abstract}

Kata-kata kunci: Persepsi, posisi strategis, public relations

\section{STUDENT'S PERCEPTIONS ABOUT STRATEGIC POSITION OF PUBLIC RELATIONS PROFESSIONALS}

\begin{abstract}
The study entitled Student's Perceptions About Strategic Position of Public Relations Professionals aims to know (a) How does a student majoring in Public Relations interpret PR Profession strategic position within the organization, (b) How does a student majoring in Public Relations PR perceive and interpret PR knowledgein application to the PR Profession, (c) How does a student perceive and interpret the ability that a Public Relations Officer ought to have.This study uses qualitative research methods with a phenomenological approach, and a theoretical perspective of social construction of reality. Respondents were taken from the third, fifth, and seventh semester as many as six people. The samples were carried out purposively. Results shows that (1) students interpret the strategic position of PR from the proximity to decision-makers which is the same as the rumours circulate around people that the closer a person to a leader the more strategic the position will be, (2) students perceive and interpret that students 'knowledge of public relations, including materials from lectures, and also the reality of PR profession, conclude that PR studies needs more aplicative skill and lecture materials (3) students perceive and interpret the ability to understand lecture materials plus a foreign language, and computers skillsthe same as in the reality where computer skills and mastering foreign languages are the things that make people seen to be more competent than others. The conclusion shows that students's views on strategic position of having public relations knowledge and the ability that a PRO ought to have is strongly influenced by prior knowledge of reality and the strategy comprehension. The interpretation of the PR science also influenced by their experience and knowledge on the science of public relations developed before they become students. The advice can be given in terms of $P R$ interpretation as public relations should be strengthened by Government PR knowledge as it is shown that students understanding on government PR is not decent enough.
\end{abstract}

Keywords: Perception, strategic position, public relations

Korespondensi: Trie Damayanti, S.Sos,M.Si., Departemen Ilmu Hubungan Masyarakat Fakultas Ilmu Komunikasi Universitas Padjadjaran, Jl. Raya Bandung-Sumedang Km.21, Email: trie.damayanti@unpad.ac.id 


\section{PENDAHULUAN}

Public Relations merupakan suatu ilmu atau seni berkomunikasi.Hal ini diungkapkan oleh beberapa ahli dan tercermin pada beberapa definisi yang mengungkapkan tentang public relations. Selain seni berkomunikasi, PR diyakini merupakan sebuah ilmu yang mendasarkan diri pada manajemen sebagai acuannya. Setiap kegiatan yang dilaksanakan harus melalui proses manajemen. Proses manajemen tersebut diadaptasi dengan menyebut sebagai Proses PR. Selain seni berkomunikasi dan manajemen, PR pun menganggap dasar setiap pekerjaan yang dilakukannya adalah opini publik, karena opini publiklah yang akan menggiring orang berpendapat, berekspresi, bersikap, bahkan berperilaku terhadap organisasi. Dari hal-hal tersebut dalam ilmunya terungkap bahwa public relations hanya bisa dilakukan jika ia ada di dalam sebuah organisasi.

Dilihat dari definisi, perkembangan ilmu, dan kemampuan, terlihat bahwa public relations merupakan suatu ilmu yang unik. Ia tidak melulu berbicara keilmuan secara membosankan. Ia tidak melulu berbicara perkembangan ilmu secara penelitian, meskipun penelitianpun merupakan suatu syarat keahlian yang harus dimiliki seorang PRO. Ia pun tidak melulu berbicara tentang filosofi, buku-buku, atau istilah-istilah rumit yang sering ada di dalam sebuah perkembangan keilmuan. PR memadukan antara ilmu komunikasi, manajemen secara keilmuan dengan keahlian yang nanti harus dimiliki seorang PRO. PRO (Public Relations Officer) adalah istilah yang diberikan pada seseorang yang memang bergelut di bidang ke-PRan, terutama jika mereka itu berada di dalam sebuah organisasi.

Skill atau keahlian merupakan kata kunci yang harus dimiliki oleh siapa saja yang ingin menjadi PRO. Di Fakultas Ilmu Komunikasi, Jurusan Hubungan Masyarakat meyakini bahwa ilmu-ilmu komunikasi, manajemen, bahkan skill menyiapkan segala 'tool of $P R$ ' merupakan menjadi dasar segala keahlian yang akan diberikan pada mahasiswanya. Seperti yang dikatakan oleh Soemirat, salah seorang guru besar Ilmu Public Relations, bahwa untuk menjadi seorang PR setidaknya ada lima kemampuan yang harus dimiliki yaitu kemampuan untuk berkomunikasi, kemampuan manajerial, kemampuan melakukan jejaring sosial, berkepribadian dan jujur, banyak ide dan kreatif (Soemirat dalam Ardianto, 2006: 35).

Masalah yang kemudian muncul adalah untuk mencapai kemampuan tadi, banyak orang yang berpendapat bahwa untuk menjadi seorang PR tidaklah perlu belajar terlalu lama dan terlalu susah. Komunikasi adalah suatu kemampuan yang bisa dipelajari sendiri bahkan sudah fitrahnya manusia melakukan komunikasi dengan manusia lain sehingga hal tersebut merupakan suatu kebiasaan yang tinggal diasah saja kemampuannya. Manajemen pun bukan merupakan ilmu yang sulit karena kemampuan manajerial seseorang biasanya terbentuk dengan sendirinya jika ia sering bergaul dan sering berada di dalam sebuah organisasi. Bahkan ada orang yang meyakini, kemampuan manajerial terkadang dimiliki tanpa disadari oleh manusia tersebut karena setiap hari manusia melakukan kegiatan manajemen, dari bangun tidur sampai malam hari, dan juga ketika ia merancang kehidupannya. Kemampuan-kemampuan lain seperti kejujuran, imajinasi, dan memiliki ide kreatif juga disinyalir merupakan kemampuan yang tidak perlu dipelajari apalagi setingkat sarjana.

Fenomena yang munculpun seolah berbicara hal yang sama. Bisa dilihat bahwa untuk menjadi seorang PR, seseorang tidak dituntut untuk memiliki gelar kesarjanaan. Bahkan background ilmu pun tidak terlalu diperhatikan oleh para pemilik perusahaan. Banyak PRO yang berasal dari IPB, UGM, ITB, atau bahkan dari universitas luar negeri yang bukan belajar mengenai (minimal) ilmu komunikasi.Ada seorang dokter atau dokter gigi yang bisa menjadi PR, fenomena ini pun terlihat terutama di perusahaan-perusahaan yang bergerak di bidang kesehatan seperti Rumah Sakit, Farmasi, dll.

Selain dari latar belakang ilmu yang tidak diperhatikan, hal lain yang terlihat adalah posisi PR dalam organisasi yang sangat tidak strategis di beberapa tempat. Hal ini terungkap di Seminar yang diadakan oleh IPRA 
beberapa waktu yang lalu yang mencoba mereposisi PR pada organisasi. Banyak perusahaan yang tidak paham bagaimana seharusnya PR ditempatkan, karena penempatan PR di dalam sebuah struktur organisasi akan menunjukkan bagaimana PR itu akan leluasa bergerak nantinya.

Selain di perusahaan swasta, PR di pemerintahanpun menunjukkan hal yang sama. Posisi yang ditempati tidak lebih dari sekedar "juru gunting" surat pembaca, atau juru foto setiap kegiatan yang dilakukan pemerintah setempat. Bahkan budaya di pemerintahan yang cenderung ABS dan birokrasi memperparah kondisi ke-PRan di pemerintah.

Kondisi seperti itu tentu bahan renungan bahkan kajian dalam setiap seminar, lokakarya, bahkan konvensi, yang dilakukan oleh organisasi-organisasi profesi seperti IPRA (International Public Relations Association) maupun Perhumas (Perhimpunan Hubungan Masyarakat). Banyak hasil yang merekomendasikan bahwa sebaiknya untuk menjadi PRO, setidaknya ia harus memiliki latar belakang Ilmu Komunikasi bahkan PR, agar ia bisa bekerja secara maksimal. Kemampuan-kemampuan yang harus dimiliki, yang setidaknya menjadi syarat seorang PR, ternyata tidak mudah dipelajari sendiri. Untuk memiliki kemampuan komunikasi, misalnya, seseorang tidak hanya dituntut untuk bisa berbicara, tapi ia pun dituntut untuk memahami apa yang diinginkan oleh pendengar atau khalayaknya, karena ternyata keefektifan sebuah proses komunikasi sangat ditentukan oleh penerimaan khalayaknya. Kemampuan manajerial pun demikian. Untuk membuat perencanaan, misalnya, bukan hanya kemampuan membuat proposal saja yang dibutuhkan, tapi kemampuan untuk memprediksi apakah perencanaan ini bisa dilaksanakan, dan strategi apa saja yang perlu dimiliki, juga kemampuan untuk membaca jauh ke depan jika masalah yang nanti muncul pada kegiatan yang sudah direncanakan.

Banyak hal selain yang telah disebutkan, menjadi acuan bagaimana seorang mahasiswa Jurusan Kehumasan nantinya terbentuk. Ia akan menjadi seorang PR yang handal yang sangat kompeten di bidang komunikasi, manajerial, dan sangat memaha- mi norma-norma pada profesinya. Kemampuan-kemampuan itu sangat tercermin pada kurikulum yang menjadi dasar seorang mahasiswa memilih keilmuannya. Mahasiswa Jurusan Kehumasan dituntut selalu aktif baik mencari perkembangan ilmu, informasi, dan dituntut selalu mengikuti perkembangan teknologi informasi. Mahasiswa Jurusan Kehumasan dituntut untuk memiliki kemampuan berbahasa yang baik, terutama bahasa asing, agar ia mampu bersaing secara global. Tapi fenomena yang terjadi di sekitar pekerjaan yang nanti akan ia gelutipun ternyata membawa pengaruh yang cukup signifikan terhadap persepsinya pada pekerjaan tersebut.

Tidaklah tertutup kemungkinan, karena manusia merupakan mahluk yang selalu berinteraksi dengan lingkungan sosialnya, mahasiswa pun mendapat informasi tidak hanya dari bangku kuliah saja. Segala informasi baik dalam bentuk berita maupun gosip, sampai pada dirinya.Informasi yang terdengar maupun yang terlihat menunjukkan profesi PR yang sesungguhnya. Sampai saat ini PR menjadi ilmu yang tertutup tidak seperti Ilmu Kedokteran untuk menjadi dokter, atau Ilmu Hukum untuk menjadi pengacara atau notaris, masih menjadi impian. Ketidakmengertian para CEO pada profesi PR, ketidakpahaman para pengambil kebijakan pada kehumasan, masih menjadi tolok ukur posisi PR di organisasi. Fenomena itu pun berpengaruh pada bagaimana mahasiswa mencoba memandang dirinya beberapa tahun ke depan.

Idealisme yang dicoba diterapkan agar mereka menjadi praktisi ke-PRan yang mumpuni menjadi terbuang percuma ketika mereka hanya mencoba mendapatkan IPK tertinggi selama kuliah, karena mereka beranggapan hanya IPKlah yang menjadi daya jual mereka untuk bersaing di dunia kerja nantinya. Skill yang dicoba dilatihkan pun menjadi sesuatu yang membuang-buang uang saja ketika yang dikejar hanyalah nilai akhir yang akan diberikan oleh dosen saja.

Ada beberapa lulusan yang berpendapat bahwa ilmu yang sesungguhnya didapat ketika ia bekerja, bahka ia berpendapat tidak mendapatkan apa-apa ketika kuliah. Ten- 
tu hal ini pun menjadi pemikiran tersendiri karena kurikulum selalu mencoba menyelaraskan antara keinginan dan kebutuhan pemakai tenaga kerja kita.Tidak sedikit perusahaan yang selalu mencari tenaga kerja dari Jurusan Kehumasan berpendapat bahwa kelebihan mahasiswa kehumasan adalah kemampuannya di dalam merancang sebuah event, dan kemampuan membuat penelitian. Tetapi ketidakpahaman mahasiswa pada posisinya dalam mencari ilmu inilah yang nanti menjadi dasar ia memandang profesinya kelak.

Profesi yang nanti akan digeluti oleh mahasiswa tidak melulu sebagai PR perusahaan. Hal itu sangat dipahami oleh mahasiswa. Bahkan untuk menjadi PR perusahaan, pekerjaan yang dilakukannya juga tidak mudah. Menurut yang mereka dapat, untuk menjadi seorang PR perusahaan ia harus mampu merancang sebuah kegiatan, ia harus mampu menjadi seorang public speaker yang baik, ia harus memiliki kemampuan membuat strategi dan taktik dalam membangun reputasi, dan ia harus mampu bekerjasama dengan publik-publik perusahaannya. Untuk menjadi seorang PR pemerintahpun, meski tidak terlalu banyak disinggung dalam perkuliahan, setidaknya menurut mereka, ia harus memiliki kemampuan berkomunikasi secara politik, ia harus memahami regulasi dan perundang-undangan yang dimiliki negara, ia pun harus mampu bekerjasama dengan wartawan (pers), dan ia harus mampu merancang alur informasi mana yang perlu untuk disampaikan pada masyarakat.

Dari fenomena-fenomena tersebut, fokus yang peneliti coba untuk dirumuskan pada penelitian ini adalah: "Bagaimana persepsi mahasiswa Jurusan Humas pada profesi public relations yang akan digelutinya?".

Identifikasi masalah dalam penelitian ini antara lain: (1). Bagaimana mahasiswa Jurusan Humas memaknai posisi strategis Profesi PR dalam organisasinya; (2). Bagaimana mahasiswa Jurusan Humas memandang dan memaknai Ilmu Kehumasan yang dimiliki untuk diterapkan pada Profesi PR; dan (3). Bagaimana mahasiswa Jurusan Humas memandang dan memaknai kemampuan yang harus dimiliki oleh seorang PRO.

\section{METODE PENELITIAN}

Metode yang digunakan pada penelitian ini adalah tradisi fenomenologi. Tradisi fenomenologi menurut Creswell adalah:

"Whereas a biography reports the life of a single individual, a phenomenological study describes the meaning of the lived experiences for several individual about a concept or the phenomenon" (Creswell, 1998: 51).

Studi dengan pendekatan fenomenologi berupaya menjelaskan makna pengalaman hidup sejumlah orang tentang suatu konsep atau gejala.

Moleong menjelaskan bahwa fenomenologi tidak berasumsi bahwa peneliti mengetahui arti sesuatu bagi orang-orang yang sedang diteliti oleh mereka.Inkuiri fenomenologis dimulai dengan diam. Diam merupakan tindakan untuk menangkap pengertian yang sedang diteliti.Mereka berusaha untuk masuk ke dalam sesuatu yangsedang diteliti. Mereka berusaha masuk ke dalam dunia konseptual para subyek yang ditelitinya sedemikian rupa sehingga mereka mengerti apa dan bagaimana suatu pengertian yang dikembangkan oleh mereka di sekitar peristiwa dalam kehidupan sehari-hari (Moleong, 2000: 9).

Littlejohn menyebutkan "phenomenology makes actual lived experience the basic data of reality" (Littlejohn, 1996: 204). Fenomenologi menjadikan pengalaman hidup yang sesungguhnya sebagai dasar dari realitas. Littlejohn lebih jauh menjelaskan bahwa fenomenologi berarti membiarkan segala sesuatunya menjadi nyata sebagaimana aslinya, tanpa memaksakan kategori-kategori peneliti terhadapnya.

Mulyana menyebutkan, pendekatan fenomenologi termasuk pendekatan subyektif atau interpretif yang memandang manusia aktif, kontras dengan pendekatan obyektif atau pendekatan behavioristik dan struktural yang berasumsi bahwa manusia itu pasif (Mulyana, 2001: 59).

Proses pengumpulan data menggunakan teknik-teknik observasi dan wawancara 
mendalam. Observasi dilakukan karena tidak banyak menuntut peranan tingkah laku atau keterlibatan peneliti terhadap kegiatan atau fenomena dari subyek yang diteliti ( $\mathrm{Su}-$ prayogo \& Tobroni, 2001: 170). Observasi merupakan metode pengumpulan data yang paling alamiah. Observasi adalah mengamati dan mendengar dalam rangka memahami, mencari jawab, mencari bukti terhadap fenomena (Suprayogo dan Tobroni, 2001: 167).

Dalam penelitian ini observasi dilakukan secara nonpartisipan, artinya peneliti tidak berlaku menjadi mahasiswa melainkan hanya mencoba menggali pengetahuan mahasiswa tentang public relations. Dalam mengobservasi mahasiswa, peneliti mencoba mengamati setiap pesan-pesan non verbal yang ada dalam setiap perilaku yang ditunjukkan untuk melengkapi penginterpretasian mereka pada makna yang mereka ketahui.

Wawancara mendalam dilakukan karena cara ini dianggap dapat memasuki dunia pikiran dan perasaan responden (Nasution, 1996: 69). Wawancara merupakan sarana untuk memperoleh informasi melalui proses tanya jawab yang dapat menghasilkan kontruksi makna bersama tentang sebuah topik tertentu.

Wawancara dilakukan secara terbuka, tidak berstruktur dan dalam suasana bebas. Peneliti mencoba menghilangkan kesan formal, meskipun karena posisi sebagai tenaga pengajar tentu sulit menghilangkan kesan tersebut.

Dalam beberapa hal ternyata peneliti merasa perlu melakukan FGD dengan para nara sumber dengan cara mengumpulkan nara sumber di suatu tempat, dan kami melakukan diskusi yang menyangkut hal-hal pemaknaan tentang posisi strategis public relations dengan cara terbuka, sehingga akan terlihat bagaimana setiap individu yang menjadi nara sumber bisa saling mempengaruhi bahkan dalam pengetahuan sekalipun. Peneliti hanya memberikan arahan dan mencoba mencatat hasil FGD dengan dilengkapi catatan-catatan tambahan seperti suasana, dan pesan-pesan nonverbal yang tampak selama proses FGD.

Seperti yang disampaikan oleh Joseph A. Maxwell dalam bukunya Qualitative Re- search Design, tujuan utama melakukan focus group interviews dan focus group discussion adalah mengeksploitasi efek kelompok. Interaksi manusia dalam sebuah kelompok akan lebih memperlihatkan data yang terlihat. Dalam konteks kelompok, setiap anggota akan terstimuli oleh ide dan pengalaman orang lain yang ada dalam kelompok tersebut (Maxwell, 1996: 69).

Pustaka yang dikaji dalam penelitian ini dapat berbentuk dokumen, baik dokumen pribadi maupun dokumen resmi. Jenis dokumen yang dimaksud adalah data berupa data statistik, agenda kegiatan, hasil penelitian, dsb. yang memiliki relevansi dengan penelitian ini.

\section{HASIL DAN PEMBAHASAN}

Pada dasarnya humas adalah sebuah profesi yang pasti selalu berada dalam organisasi. Banyak definisi PR yang menunjukkan hal demikian, salah satunya yang dicetuskan oleh Rex Harlow yang menyatakan bahwa:

"Public relations' role as a management function that help establish and maintain mutual lines of communication, understanding, acceptance, and cooperation between an organization and its publics." (Johnston \& Zawawi, 2004: 7).

Jika dicoba diterjemahkan, fungsi public relationsadalah untuk membangun dan menjaga komunikasi yang seimbang sehingga tercipta pemahaman, penerimaan, dan kerjasama antara organisasi dan publiknya.

Posisi strategis adalah posisi dimana PR adalah suatu profesi yang memiliki aksesibilitas yang tinggi baik untuk tingkat manajer maupun bawahan. Pemahaman seperti itu sesuai dengan pemahaman di lingkungan masyarakat yang selalu menempatkan pemimpin sebagai seorang yang memiliki kekuasaan, jadi jika ada orang yang setidaknya memiliki kedekatan dengan pemimpin yang memiliki kekuasaan tentu akan memungkinkan bagi dirinya berdekatan dengan kekuasaan sehingga memudahkan bagi seorang PR mengendalikan dan memperbaiki mas- 
alah-masalah yang mungkin muncul pada pekerjaannya. Aksesibilitas yang tinggi hanya bisa didapat jika PR memang berdekatan dengan top manajemen.

Posisi strategis menurut mahasiswa semester awal adalah posisi dimana PR bisa mengendalikan kebijakan. Secara umum pengendali kebijakan memang pasti berada pada posisi atas, banyak orang yang meyakini itu. Itulah sebabnya banyak orang yang merasa memiliki posisi biasanya mencoba mengendalikan keadaan bahkan bersikap seenaknya pada orang yang berada di bawahnya. Prinsip ini secara umum tidak salah meskipun kita bisa melihat pada perkembangannya terkadang kebijakan dibuat bukan oleh orang yang memiliki posisi strategis tapi karena desakan dari mayoritas atau sekumpulan orang yang merasa memiliki jumlah banyak.

Bahkan setinggi apapun posisi seseorang jika didesak oleh sejumlah massa biasanya kebijakan akan dibuat berdasarnya keinginan orang banyak tersebut

Tapi persepsi mahasiswa semester awal berbeda mengenai PR pemerintah. Ketidaktahuan ini bisa disebabkan beberapa hal; pertama, citra Pemda memang tidak terlalu baik di mata publiknya; kedua, tidak banyak kegiatan pemerintah yang sesuai dengan kegiatan ke-PR-an seperti yang dikenal mahasiswa; ketiga, buku-buku yang mengenalkan konsep-konsep PR memang lebih banyak mencontohkan kegiatan di perusahaan. Perusahaan (swasta) sampai saat ini di masyarakat memang lebih memiliki citra positif dalam menunjukkan kinerja.Hal-hal yang berkaitan dengan korupsi, kolusi dan nepotisme merupakan tiga hal yang melekat pada citra pemerintahan, seolah-olah hal itu tidak ada pada perusahaan. Terlihat jelas dari nara sumber jika mereka tidak begitu semangat jika harus mendiskusikan tentang PR di pemerintahan karena menurut mereka tidak pernah ada kegiatan kehumasan yang terlihat di permukaan.

Mahasiswa semester lebih tinggi mencoba memaknai posisi strategis bukan hanya dari dimana posisi PR dalam sebuah organisasi saja, bahkan dengan tegas mengatakan PR tidak harus berada dalam sebuah perusahaan.Pemahaman mereka lebih menekank- an pada fungsi dari ke-PR-an tersebut yang sangat strategis. Strategis dimaknai tidak hanya dilihat pada kedekatan dengan pemberi kebijakan tapi lebih pada kegiatan-kegiatan ke-PRan yang membuat posisi mereka lebih fleksibel di mata publiknya. Mereka lebih melihat posisi strategis adalah posisi dalam melaksanakan fungsi-fungsi kegiatan PR. Mereka pun mencoba memaknai posisi strategis sebagai posisi yang menghasilkan uang. Seperti yang diinginkan oleh masyarakat.

Jika mengacu pada perkerjaan PR yang memang menuntut pemikiran dan resiko yang sangat tinggi, besarnya penghasilan sangatlah berimbang, hal tersebut pernah peneliti tanyakan pada seorang konsultan PR Djaka Winarso dari Socio Komunikasi, ia mengatakan bahwa "Kalau sedang melayani klien apalagi kalau perusahaannya lagi bermasalah, bagi PR waktu 24 jam tidak cukup". Hal itupun dikuatkan oleh Magdalena Wenas di tempat yang terpisah ketika menceritakan pengalamannya ketika menjadi PR Bank Suma, "Kalau diibaratkan rasanya mandi juga susah, tiap jam kita harus tahu informasi tentang perusahaan kita, apalagi jaman dulu belum musim BB seperti sekarang”. Baik Djaka maupun Magdalena mengamini memang pekerjaan PR baik yang ada di perusahaan ataupun sebagai konsultan tidaklah mudah, dengan kata lain memang posisi strategis bisa dikatakan sebagai posisi yang harus selalu ready dan well informed.

Beberapa hal yang diungkapkan oleh para praktisi itu memang tidak diketahui oleh mahasiswa karena sebagai mahasiswa mereka biasanya dibekali hal-hal yang bersifat ideal sedangkan praktisi sudah mendapatkan pengalaman-pengalaman di luar keidealan tersebut. Meskipun demikian pengalaman mereka di beberapa mata kuliah yang menuntut mereka membuat sesuatu yang tadinya terasa tak mungkin dilakukan oleh mahasiswa, seperti mata kuliah PR Event yang menuntut setiap kelompok mahasiswa membuat sebuah event besar yang minimal tingkatnya lokal (Bandung), ternyata membuat mereka membuka mata bahwa menjadi PR tidak hanya harus bagus saja, tapi ada hal-hal yang harus mereka lakukan seperti kegagalan misalnya. Hal inilah yang membedakan pemahaman maha- 
siswa semester III dan V.

Mahasiswa semester VII cenderung lebih berhati-hati dalam memberikan pandangan tentang posisi strategis PR, "PR dikatakan memiliki posisi strategis karena memang mereka menjalankan fungsi manajemen..","...kalau fungsi manajemen kan tidak harus di perusahaan, di konsultan malah kalau bikin EO (Event Organizer - penulis) juga harus pakai fungsi manajemen..”. Pernyataan itu menunjukkan bahwa mereka sudah lebih banyak tahu tentang PR tidak hanya sebagai 'manajer tok'.Mereka menyatakan bahwa fungsi manajemen membuat mereka memiliki posisi strategis, betul jika fungsi manajemen bisa dilakukan kalau PR berada pada posisi manajerial, tapi bukan berarti ketika mereka tidak memliki posisi manajerial mereka tidak bisa melakukan fungsi manajemen. Dari data yang mereka berikan mereka meyakini bahwa fungsi manajemen dalam manajemen disebut dengan Planning, Organizing, Actuating, dan Controlling (POAC) atau dalam PR disebut dengan Proses PR kalau menurut Cutlip, Center \& Broom dikenal dengan Fact Finding, Planning, Communicating, dan Evaluasi. Kegiatan proses PR ini memang jika PR menduduki level karyawan tidak mungkin dilakukan, tapi jika pada konsultan PR mereka bisa melakukan atas kehendak dari perusahaan tersebut. Dengan kata lain mereka memaknai posisi strategis dari kegiatan proses manajerial untuk membuat dan merancang kegiatan-kegiatan PR.

Menurut mahasiswa tingkat akhir kemampuan mereka dalam menganalisis masalah yang muncul dari hasil penelitian yang didapat menjadi dasar mereka menyusun strategi menjawab permasalahan yang ada. Mereka diminta untuk berandai-andai menjadi PR sebuah perusahaan dan menyusun strategi penyelesaian masalah yang harus diketahui oleh perusahaan tersebut. Disini akan terlihat bahwa menjadi PR bukanlah pekerjaan yang mudah, yang membuat posisi PR strategis karena mereka harus membuat daya tawar yang menarik.

Di kemasyarakatan hal tersebut tidak jauh berbeda, orang biasanya dianggap memiliki posisi strategis ketika ia memiliki daya tawar yang tinggi. Kalau boleh peneliti member- ikan contoh seperti buruh yang memiliki penghasilan rendah, hal itu disebabkan karena ia tidak memiliki posisi tawar yang lebih, dengan kemampuan yang pas-pasan dan kebutuhan akan pekerjaan, membuat ia rela 'dibayar berapa pun' asal tetap bekerja. Ia dianggap memiliki posisi yang menarik jika banyak hal yang ia tawarkan dan bisa dinegosiasikan. Hal ini memang diperkuat masih oleh Djaka Winarso yang pernah menceritakan pada peneliti tentang kesulitan dalam meyakinkan klien tentang proposal yang ditawarkan. "Saya pernah beberapa kali buat proposal, dan berulang kali juga ditolak klien, karena dianggap kegiatan yang saya rancang kelewatan.." Sementara Magdalena Wenas di tempat yang terpisah lebih menekankan pada pemahaman CEO pada kegiatan yang dirancang PR, "Banyak CEO yang menganggap kegiatan yang dirancang PR baik itu untuk perbaikan image atau mempublikasikan sesuatu dianggap menghambur-hamburkan uang..". Pada kesempatan lain di sebuah seminar yang dilakukan oleh International Public Relations Association (IPRA), Noke Kiroyan dari Kiroyan \& Partners juga mengungkapkan hal senada bahwa "Sestrategis apapun posisi seorang PR harus diawali dengan pemahaman CEO pada posisi PR itu sendiri", dengan kata lain posisi strategis PR sangat ditentukan pada pemahaman CEO pada fungsi-fungsi PR. Hal-hal tersebut tentu senada dengan pemahaman mahasiswa semester VII pada posisi strategis PR tersebut.

Meskipun demikian pemahaman mereka pada posisi PR di pemerintah juga minim, meskipun pemahaman mereka terbantu dari informasi yang didapat dari teman-teman seangkatannya yang sedang melakukan jobtraining di kantor pemerintahan. Mereka memaknai posisi PR di pemerintahan sebagai pekerjaan yang kurang menarik, meskipun dari informasi yang mereka dapat dari teman-teman yang lain bahwa PR Pemerintah bukanlah posisi yang tanpa ada pekerjaan. Masih menurut mereka pekerjaan dan posisi PR di pemerintahan sangat tidak strategis apalagi jika harus banyak menghadapi wartawan tanpa surat kabar yang jelasjelas hanya menginginkan 'amplop' yang 
dibagikan. Dengan kata lain PR kerjaannya hanya jadi tukang bagi amplop. Sangatlah berbeda dengan bekal yang mereka dapat selama kuliah, mahasiswa dibekali untuk dapat membuat relasi dengan media dalam hal ini orang media yang memiliki kekuasaan dalam menentukan berita mana yang akan ditayangkan atau dalam pengertian PR disebut dengan 'gatekeeper' yang jelas bukan wartawan amplop. Ketika menjadi PR pemerintah yang dihadapi hanya wartawan amplop dimana kita tidak perlu menggunakan skill tertentu dalam menghadapinya.Pemahaman tentang posisi PR di pemerintah itu tentu didasarkan pada pemahaman masyarakat tentang fungsi dan kegiatan pemerintah itu sendiri, jika dihadapkan dengan pengertian protokoler masyarakat lebih memahami sebagai suatu kegiatan upacara yang rutin dilakukan oleh pemerintah.Tertanam di benak masyarakat suatu upacara (yang biasanya menggunakan bendera) dan melibatkan pejabat-pejabat pemerintah. Pidato-pidato panjang dan membosankan diakhiri dengan doa sebagai penutup, merupakan rangkaian kegiatan protokoler yang dipahami masyarakat. Pemahaman itu juga mendasari mahasiswa pada pemahaman tentang protocol ketika mereka mendapatkan informasi dari orang lain tentang humas yang berada di posisi protokoler. Mahasiswa merasa posisi PR di pemerintah sangat tidak menjanjikan dan tidak menawarkan daya tawar yang baik bagi posisinya.

Pada awalnya Public Relations bukanlah sesuatu yang bisa dipelajari secara textbook, barulah ketika seorang yang bernama Edward L.Bernays dalam bukunya Cristallizing Public Relations menunjukkan bahwa Public Relations bisa dipelajari secara konseptual. Konsep-konsep Public Relations yang selama ini hanya terlihat pada hasil akhir kegiatan mulai bisa dipelajari sehingga mulai memunculkan ahli-ahli di bidang konsep-konsep PR seperti Scott M. Cutlip, Allen H. Center, Glenn M. Broom, Frank Jefkins, sampai dengan Grunig. Grunig bahkan yang mengenalkan Four Models of Public Relations yang terdiri dari (1) PR as Press Agentry/Publicity Model; (2) PR as Public Information model; (3) Two symmetrical model; (4) Two Asymmetrical Model.
Saat ini, terutama mahasiswa-mahasiswa Jurusan Humas, diyakinkan bahwa profesi yang akan mereka geluti nanti sesuai dengan ilmu yang mereka dapat selama kuliah. Hal itu yang coba dimaknai oleh Shelly dan Nindy.Sebagai mahasiswa semester III mereka mengakui bahwa mereka baru mendapatkan pemahaman tentang ilmu humas adalah sewaktu mereka kuliah Pengantar Ilmu Humas.Manajemen dan komunikasi adalah gerbang ilmu awal yang harus mereka pelajari, mereka meyakini bahwa (terutama) manajemen adalah ilmu dasar yang harus dikuasai karena pengetahuan-pengetahuan selanjutnya sangat berdasar pada ilmu itu. Sementara komunikasi jelas merupakan ilmu aplikatif yang nanti akan banyak dimanfaatkan pada kegiatan-kegiatan PR.

Sesuatu yang menarik memang berdasarkan perkembangan pengetahuan yang terjadi di masyarakat. Baik manajemen maupun komunikasi bukanlah hal yang aneh di masyarakat, orang kerap mendengar istilah manajemen maupun komunikasi, itulah sebabnya ketika seseorang memilih fakultas untuk kuliah orang cenderung memilih yang lebih dimengerti daripada nama fakultas yang mungkin belum pernah mereka dengar sebelumnya, seperti fakultas kelautan dan teknologi perikanan misalnya. Masyarakat awam pun cenderung memaknai manajemen sebagai ilmu untuk menjadi manajer, seolah-olah orang yang mempelajari manajemen pasti akan menjadi manajer, masyarakat awam pun memaknai komunikasi sebagai alat untuk berbicara dengan orang lain, sehingga kalau ingin pintar berbicara dengan orang lain kuliahlah di komunikasi.

Selain dari faktor definisi yang cenderung mengawali dengan manajemen, di masyarakat orang memang cenderung lebih mengenal manajemen terlebih dahulu sebagai ilmu daripada komunikasi. Orang tidak akan menanyakan tentang apa itu manajemen, atau ketika seseorang diterima di fakultas ekonomi jurusan manajemen, orang lain tidak akan terlalu banyak bertanya, tapi beberapa waktu yang lalu masih banyak orang yang tidak tahu tentang komunikasi sebagai ilmu terlihat dari ketika ada mahasiswa yang diterima di Fikom, masyarakat awam men- 
ganggap 'kom' yang ada pada Fikom sebagai komputer, bukan komunikasi. Ketika saat ini orang sudah mulai memahami komunikasi sebagai ilmu, orang masih cenderung beranggapan untuk bisa berkomunikasi tidak perlu susah-susah sekolah, karena sudah dilakukan setiap hari.

Mahasiswa semester V menganggap profesi PR perlu ilmu yang banyak, karena ternyata untuk jadi PR yang handal tidak cukup pintar bicara dan membuat event saja, Mahasiswa menunujukkan bahwa mata kuliah yang pernah mereka ambil mempengaruhi cara mereka melihat ilmu yang perlu dikuasai untuk menjadi seorang PR Profesional. Bisa dilihat bahwa mereka sangat menaruh minat pada ilmu-ilmu yang berkaitan dengan praktik mereka menjadi seorang PR ataupun event organizer. Materi-materi yang ada pada beberapa mata kuliah itu memang menuntut mereka untuk mengahabiskan waktu bahkan biaya yang tidak sedikit dalam membuat praktikumnya. Tapi hasil yang didapat ternyata sangat berkesan bagi mahasiswa sehingga tidak sedikit mahasiawa terutama yang sudah menduduki semester V berpendapat bahwa PR adalah Event Organizer. Merekapun sudah mulai terbuka bahwa PR bukanlah Marketing, seperti yang selama ini orang awam ketahui. Jika melihat pada fenomena yang terjadi di lingkungan masyarakat awam, orang memang cenderung lebih menganggap bahwa Public Relations adalah Marketing. Terlihat di beberapa perusahaan yang jarang menampilkan public relations sebagai salah satu divisi/departemen yang ada di perusahaannya. Perusahaan lebih cenderung menamai salah satu divisi/departemennya dengan nama 'maketing division', 'marketing communication', 'corporate secretary', dll. Ketiadaan nama PR sebagai salah satu divisi atau departemennya disebabkan karena marketing lebih mudah dipahami. Pada dasarnya masyarakat lebih memahami marketing, sebagai ilmu yang mempelajari cara menjual barang, daripada public relations yang berusaha memperbaiki image. Agak sulit untuk mencoba memahami apalagi ketika dikatakan bahwa PR tidak tidak menjual barang, tapi lebih menjual image, orang akan bingung bagaimana cara menjual image. Cara berpikir marketing setidaknya lebih mudah, jual barangnya, hitung untungnya. Kalau PR harus berpikir bagaimana orang berpikir tentang perusahaan kita, dsb. Itulah sebabnya orang cenderung lebih tahu tentang marketing daripada PR, demikian juga dengan mahasiswa, awalnya mereka tahu tentang marketing, mereka sedikit tahu tentang public relations, ketika mereka kuliah mereka baru paham jika marketing dan public relations adalah dua hal yang berbeda tapi memiliki beberapa persamaan terutama dalam hal peraihan keuntungan.

Hal-hal seperti itu dibenarkan pula oleh Elizabeth Gunawan Ananto (Ibu Ega), yang kebetulan pada saat ini sedang menjabat sebagai Presiden IPRA, beliau kebetulan memiliki latar belakang akademisi juga karena beliau adalah pengajar di MMComm Trisakti Jakarta. Ibu Ega mengakui jika latar belakang pendidikannya adalah Sastra Inggris Unpad tapi kemudian ketertarikannya di bidang komunikasi khususnya PR, membuat ia melanjutkan studinya sampai meraih Gelar Ph.D di bidang public relations, bahkan yang menjadi promotornya adalah James Grunig itu sendiri. Beliau mengakui bahkan di tingkat universitas sekaliber Trisaktipun masih banyak orang yang hanya memandang sebelah mata pada perkembangan ilmu PR, terbukti ketika ia mencoba membuat pascasarjana di bidang komunikasi, Trisakti memberikan izin dengan menempel pada Magister Manajemen (MM) dengan alasan MM lebih laku untuk 'dijual', sehingga dibuatlah MMComm seperti sekarang ini. Kebetulan sekali perkembangan PR memang membuat ilmu PR tidak bisa berdiri sendiri, ia akan lebih berkembang jika memahami perkembangan manajemen dalam bidang strategisnya dan ia akan lebih 'berwarna' jika perkembangan teknologi komunikasi dan informasi diikuti. Menurut beliau marketingpun memiliki perkembangan yang cukup signifikan, meskipun masyarakat lebih memahami marketing sebagai seni 'menjual', ternyata dengan perkembangan teknologi komunikasi dan informasi membuat marketing harus lebih pintar dari 'menjual', sehingga dibutuhkanlah kepiawaian seorang public relations dalam mengolah pesan. Masih 
menurut beliau perkembangan marketing dan PR sudah sangat pesat sehingga sulit untuk memisahkan keduanya, bahkan PR sendiri banyak menggunakan konsep-konsep yang ada dalam marketing untuk kepentingannya, seperti konsep RoI (Return of Investment) yang selama ini digunakan oleh marketing untuk mengukur keuntungan, saat ini mulai digunakan oleh Public Relations untuk mengukur keberhasilan kegiatan ke-PRan. Menurutnya salah satu kelemahan PR adalah ketidakmampuan mengukur keberhasilan, karena citra ataupun reputasi adalah sesuatu yang bersifat 'intangible' (tidak terukur). Ketidakmampuan mengukur sesuatu yang bersifat intangible membuat perusahaan sulit untuk menentukan kebijakan jangka panjang perusahaannya, untuk itulah pada perkembangannya PR mulai menggunakan RoI untuk melihat perbaikan citra maupun reputasi dari perusahaan.

Masih menurut mahasiswa semester VII, dari pandangan yang mereka fahami, ilmu PR adalah ilmu yang berkaitan dengan marketing dan hal-hal yang bersifat membuat event, dsb. Bagi mereka agak heran ketika mereka pun dituntut untuk memahami filsafat bahkan metodologi penelitian, terlihat dari mimik muka maupun nada suara yang seoleh-olah menunjukkan keheranan. Mereka tahu bahwa setiap mata kuliah yang diberikan pasti akan memiliki pengaruh positif pada profesi yang nanti akan digeluti tapi mereka masih belum mengerti apa fungsi filsafat maupun metodologi penelitian nantinya. Bagi mereka materi yang terkandung pada mata kuliah itu sangatlah sulit, meskipun mereka sudah membayangkan kesulitan itu sebelum mata kuliah itu didapat.

Kemampuan mahasiswa dalam meneliti ternyata menurut Teddy Kharsadi salah seorang praktisi PR yang aktif di Perhumas mengakui bahwa salah satu kelebihan lulusan Fikom dibandingkan dengan lulusan lain yang mungkin hanya berangkat dari diploma 1, 2, atau 3 adalah kemampuan meneliti. Tanpa disadari oleh mahasiswa bahwa pengetahuannya di bidang penelitian ternyata menjadi nilai tambah bagi dirinya. Tapi hal itu memang sesuai dengan realitas yang berkembang di masyarakat segala sesuatu yang berkaitan dengan penelitian ataupun riset bukan sesuatu yang bisa dibanggakan, bahkan cenderung dianggap tidak menarik. Banyak inovasi-inovasi yang ditemukan dan dibuat oleh orang Indonesia, tapi kita cenderung kurang menghargai bahkan lebih menyukai temuan-temuan yang berasal dari luar negeri.Fenomena seperti yang mendorong seseorang menjadi tidak terlalu tertarik pada bidang penelitian, apalagi ketika dikaitkan bahwa kajian penelitian hanya bisa dilakukan oleh orang-orang 'pintar' saja.

Tapi temuan yang menarik dari data yang terkumpul baik mahasiswa semester III, $\mathrm{V}$, ataupun VII menganggap bahwa sebanyak apapun ilmu yang dipelajari tidak akan terlalu berguna jika profesi PR itu untuk di pemerintahan. Citra yang tidak terlalu baik pada profesi humas di pemerintahan yang membuat mahasiswa Jurusan Humas tidak memiliki interest terhadap profesi PR di pemerintah sehingga mereka menganggap ilmu yang mereka miliki hanya bisa digunakan untuk PR di perusahaan, ataupun untuk menjadi PR konsultan. Seolah-olah pekerjaaan humas di pemerintahan lebih mudah dan tidak memerlukan keterampilan yang khusus. Tidak terlalu terlihatnya kegiatan humas di pemerintah, ataupun usaha yang dilakukan pemerintah untuk membuat citranya lebih baik, atau tidak dikenalnya pegawai humas yang ada di pemerintah, membuat masyarakat pun cenderung tidak menganggap humas perlu ada di pemerintah. Konsep-konsep yang diberikan dan dikenalkan pada mahasiswa pun lebih banyak yang dicontohkan di perusahaan swasta, asosiasi profesinya pun lebih banyak ditujukan untuk humas perusahaan bukan untuk humas pemerintah. Ketika anggota asosiasi berkumpul pun lebih banyak menceritakan perkembangan PR di perusahaan bukan pemerintahan.

Public Relations adalah sebuah profesi yang setidaknya harus memiliki banyak kemampuan. Menurut PR Reporter, Tips \& Tactics, setidaknya Public Relations memiliki empat kewajiban utama yaitu: Sensor of social change, Corporate conscience, Communicator, dan Corporate monitor. Dari empat kewajiban utama itu dikemukakan bahwa aktivitas yang dilakukan oleh public rela- 
tions berkisar antara: communication, publicity, promotions, press agentry, integrated marketing, issues management, crisis management, press secretary/public information officer, public affairs/lobbyist, financial relation, community relations, ilnternal relations, industry relations, minority relations, media relations, public diplomacy, event management, sponsorship, cause/relationship, marketing, fundraising.

Begitu banyaknya aktivitas yang dilakukan seorang PR menunjukkan begitu banyak kemampuan yang harus dimiliki PRO. Ia tidak cukup hanya memiliki pengetahuan tentang komunikasi dan manajemen saja, ia bahkan tidak cukup hanya mengandalkan teori-teori dan konsep-konsep yang ada dalam buku teks yang dibaca selama masa kuliah. Ia harus lebih banyak 'membaca' dari pengalaman orang lain dan perkembangan jaman, ia harus lebih banyak menggali informasi yang sedang berkembang dan mencoba menerapkan pada profesinya di kemudian hari.

Hal seperti itu ternyata belum sepenuhnya dipahami oleh mahasiswa semester III, dengan pengalaman mereka pada ilmu PR yang belum banyak, mereka masih menganggap profesi PR adalah profesi yang tidak terlalu membutuhkan terlalu banyak skill, bahkan mereka beranggapan untuk mempelajari yang lain-lain di luar yang dipelajari selama kuliah bisa dilakukan secara otodidak

Mahasiswa semester akhir beranggapan bahwa menjadi sarjana adalah tolok ukur kemampuan seorang PR yang tidak bisa disamakan dengan program diploma. Mungkin hal ini juga yang mendorong banyak orang tua menghendaki anak-anaknya berkuliah di komunikasi, tidak bisa dipungkiri sampai saat ini masyarakat kita masih memandang gelar sarjana lebih tinggi daripada non gelar, dengan kata lain gelar didapat, pekerjaan pun didapat.

Mahasiswa semester V sudah mulai memaknai kemampuan yang harus dimiliki public relations pada hal-hal yang bersifat khusus. Diakui oleh mereka hal ini disebabkan sudah bertambahnya materi yang mereka dapat, dan informasi dari kakak angkatan mereka pada bayangan yang akan mereka dapat di semester-semester selanjutnya.
Dari percakapan itu bisa dilihat bahwa mahasiswa semester V sudah mulai kaya pada pengetahuan dan kemampuan yang harus dimiliki. Yang menarik justru setiap ditanya mengenai kemampuan ataupun materi, mereka selalu menyebutkan kemampuan membuat event selalu disebutkan di awal pembicaraan padahal mata kuliah PR event baru diberikan di semester VI, dengan kata lain sebenarnya mereka belum mendapatkan mata kuliah itu tapi di benak mereka sudah tertanam bahwa kemampuan itu menjadi kemampuan inti seorang public relations. Peneliti sempat menanyakan hal tersebut pada saat FGD, dan menurut mereka, mereka mendapatkan informasi tersebut dari kakak angkatan mereka dan mereka sendiri pernah melihat dan menyaksikan kegiatan yang dirancang oleh kakak kelas itu di tahun lalu sehingga mereka sudah memiliki bayangan pada apa yang dibuat oleh mahasiswa di semester VI nantinya.

Dari pemahaman mereka itu terlihat bahwa mereka menganggap bahwa ketrampilan yang sifatnya aplikatif wajib dimiliki oleh setiap mahasiswa, selain itu mereka juga berpendapat bahwa skill itu sangat berpengaruh pada profesi PR itu nantinya. Keterampilan aplikatif itu dianggap cukup sulit karena mereka harus memanfaatkan ilmu lain bahkan mereka harus berhadapan dengan 'orang lain' selain dosen atau mahasiswa lain di fakultas ini. Realitas ini yang membentuk pemahaman bahwa PR adalah ilmu yang aplikatif dan bisa digunakan pada saat bekerja nantinya, bahkan kecenderungan yang mulai muncul di masyarakat adalah bagaimana seseorang bisa membuat pekerjaan bukan bekerja di mana menjadi pokok pemikiran mahasiswa di dalam memandang ilmu-ilmu aplikatif tersebut.Menurut mereka setidaknya kalau mereka tidak menjadi PR mereka bisa memanfaatkan itu di event organizer, tapi kalau mereka harus menjadi PR kemampuan itu menjadi tolok ukur keberhasilan profesi mereka.

Menarik memang perkembangan pengetahuan masyarakat pada konsep 'bekerja', selama ini orang seolah dituntut masyarakat untuk menjadi seorang pekerja, atau mempunyai alamat kantor yang jelas. Orang yang menjadi karyawan atau pekerja di suatu tem- 
pat seolah-olah memiliki status sosial yang lebih tinggi dibandingkan dengan orang yang tidak memiliki alamat kantor, bahkan seorang wiraswasta sekalipun beberapa waktu yang lalu terkadang dianggap pengangguran di masyarakat. Hal ini terlihat pada formulir-formulir dimanapun yang selalu menuntut seseorang mengisi kolom pekerjaan sebagai pegawai di bidang tertentu, tidak pernah ada isian kolom pekerjaan pada wiraswasta atau pengusaha, kalaupun ada dimasukkan pada kolom 'lain-lain'. Tapi perkembangan sekarang menuntut lain, masyarakat sudah bisa menghargai orang yang memiliki usaha sendiri, meskipun usaha tersebut dilakukan dari rumah sekalipun. Masyarakat sudah mulai bisa melihat bahwa tolok ukur keberhasilan bukan dilihat dari alamat kantor, tapi lebih pada penghasilan yang diterima. Selama orang tersebut memiliki penghasilan berarti ia memiliki pekerjaan. Realitas yang berkembang itulah yang menjadi dasar mahasiswa menganggap bahwa kemampuan skill yang aplikatif akan sangat bermanfaat bagi mereka di kemudian hari sehingga mereka sangat menaruh minat pada mata-mata kuliah tersebut.

Mirip dengan mahasiswa semester $\mathrm{V}$, Yunia dan Manggiasih dari semester VII menanggap bahwa kemampuan-kemampuan dasar seorang PR adalah hal-hal yang sifatnya aplikatif, tetapi selain itu menurut mereka hal-hal yang bersifat strategis juga perlu dimiliki oleh PR.

Ketika disinggung tentang penguasaan bahasa asing, seperti yang diungkapkan mahasiswa semester V, mereka berpendapat bahwa penguasaan bahasa asing memang wajib dimiliki semua mahasiswa, bukan hanya untuk keperluan profesi PR saja. Mahasiswa PR memang dituntut untuk menguasai bahasa Inggris. Realitas yang berkembang di masyarakatpun memang menunjukkan bahwa semenjak kehadiran media seperti MTV di TV swasta nasional, membuat orang tidak segan menggunakan bahasa Inggris kapan pun dan dimana pun, bahkan tidak perlu takut dengan susunan kata ataupun aturan yang salah. Penguasaan bahasa Inggris bukan lagi sesuatu hal yang aneh bahkan dalam menterjemahkan pun orang tidak perlu bersu- sah payah mendatangi 'translatter', sudah banyak program-program komputer yang menawarkan hal tersebut. Realitas yang terbentuk itu memang terlihat membentuk pemikiran mahasiswa dalam mencoba memaknai kemampuannya dalam berbahasa asing, terutama bahasa Inggris.

\section{SIMPULAN}

Dari hasil penelitian yang sudah dianalisis dan dicoba diinterpretasi, peneliti menyimpulkan: (1). Pemaknaan dan penilaian mahasiswa pada posisi strategis Public Relations mereka lihat dari posisi secara organisasi, semakin dekat dengan posisi puncak akan semakin memudahkan mereka dalam membuat kebijakan. Sesuai dengan realitas yang berkembang di masyarakat bahwa posisi strategis adalah posisi yang bisa membuat atau dekat dengan kebijakan. Pada profesi public relations, hal itu ditunjukkan dengan posisi yang setidaknya bisa berhubungan langsung dengan direktur atau pembuat kebijakan. Tetapi mahasiswa memaknai bahwa posisi strategis itu tidak berlaku pada posisi PR di humas pemerintah, karena menurut mereka posisi humas dalam pemerintahan sangat jauh dari ideal, dan tidak menunjukkan posisi yang strategis baik secara organisasi maupun secara fungsi; (2). Pemaknaan mahasiswa pada Ilmu Kehumasan yang nanti akan diterapkan pada profesi public relations mereka lihat dari materi-materi kuliah yang pernah didapat selama kuliah, hal inilah yang membedakan pemaknaan mahasiswa semester III, V, maupun VII. Pemaknaan mereka sangat tergantung pada pengalaman mereka mendapatkan mata kuliah, jika mahasiswa semester III menganggap bahwa Ilmu Kehumasan yang harus dimiliki untuk diterapkan pada profesi public relations berkisar antara ilmu manajemen dan komunikasi karena selama mereka kuliah mereka baru dikenalkan hal tersebut, mahasiswa semester $\mathrm{V}$ menganggap bahwa selain manajemen dan komunikasi yang paling penting adalah ilmu marketing karena ternyata public relations sangat berdekatan dengan marketing dan pengetahuan tentang event organizer hal itu terjadi karena mahasiswa semester $\mathrm{V}$ su- 
dah mendapatkan materi lebih banyak dari semester III. Sementara mahasiswa semester VII sesuai dengan pengalamannya pada materi perkuliahan yang pernah mereka dapat menganggap bahwa semua materi yang pernah diberikan selama kuliah sangat diperlukan dalam penerapan di profesi PR. Tetapi baik mahasiswa semester III, V, ataupun VII menganggap bahwa materi-materi apapun yang pernah diberikan selama kuliah tidak akan diterapkan jika mereka bekerja sebagai humas di pemerintahan; dan (3). Pemaknaan pada kemampuan yang harus dimiliki seorang PRO pada setiap mahasiswa di setiap semester yang berbeda memaknai dengan cara yang berbeda pula sesuai dengan pengalaman dan pemahaman mereka pada hal-hal tersebut. Mahasiswa semester III menganggap bahwa seorang PRO harus memiliki kemampuan sebagai komunikator sesuai dengan pengalaman mereka selama menjadi mahasiswa dan pemahaman awal di masyarakat bahwa seorang public relations harus pintar bicara dan tampil di muka umum, mahasiswa semester $\mathrm{V}$ menyatakan bahwa seorang PRO harus memiliki kemampuan dalam membuat event, iklan, release, bahasa Inggris, dan penguasaan komputer karena pengalaman mereka selama menjadi mahasiswa menuntut mereka untuk menguasai hal-hal tersebut, sementara mahasiswa semester VII beranggapan bahwa mereka sepakat dengan mahasiswa semester $\mathrm{V}$ hanya penguasaan komputer dan bahasa Inggris bukanlah sesuatu yang baru dipelajari selama kuliah tapi penguasaan awal yang memang menjadi kewajiban seorang mahasiswa bahkan mereka menambahkan penguasaan komputer harus dimiliki sesuai dengan perkembangan jaman. Tapi baik mahasiswa semester III, V, ataupun VII masih menganggap bahwa untuk menjadi humas di pemerintah tidak diperlukan kemampuan yang terlalu sulit karena pekerjaan humas di pemerintahan tidaklah terlalu banyak.

Dalam membantu mahasiswa memaknai berbagai hal tentang keprofesian PR, Fikom sudah melakukan hal yang cukup baik, terbukti dari pemahaman mahasiswa pada posisi strategis, Ilmu Kehumasan, maupun kemampuan yang harus dimiliki sudah sesuai dengan yang diberikan. Hal itu terbukti den- gan diuji secara triangulasi data dari sumber-sumber yang kompeten.

Berdasarkan hasil penelitian ini, ada beberapa saran yang diberikan, diantaranya: (1). Pemahaman mahasiswa pada posisi strategis menunjukkan bahwa posisi ideal menjadi kunci sesuatu posisi dianggap strategis. Mahasiswa pun perlu untuk mengetahui bahwa meskipun posisi tidak ideal bukan berarti posisinya tidak strategis; (2). Pemaknaan mereka pada Ilmu Kehumasan juga jangan sampai membuat mereka menganggap materi lain yang diberikan selama kuliah tidak diterapkan di praktek kehumasan. Mahasiswa pun perlu pengayaan pada materi-materi yang ternyata bisa diterapkan di humas pemerintah; dan (3). Pemaknaan mahasiswa pada kemampuan yang harus dimiliki PRO juga jangan menjadi harga mati bahwa hanya kemampuan itu yang menjadi dasar profesi PR. Kemampuan itu harus diikuti dengan kesiapan mereka berwirausaha karena ternyata mahasiswa juga sudah menyadari bahwa kemampuan yang dimiliki bisa dimanfaatkan jika mereka tidak menjadi seorang PRO.

\section{DAFTAR PUSTAKA}

Ardianto, E. (2006). Dasar-dasar public relations. Bandung: Remaja Rosdakarya.

Bogdan, R. \& Steven J. T. (1975). Introduction to qualitative research methods: a phenomenological approach to social sciences. New York: John Wiley \& Sons

Bungin, B. (2003). Analisis data penelitian kualitatif. Jakarta: PT. RajaGrafindo Persada

Berger, P. L. \& Luckman, T. (1990). Tafsir sosial atas kenyataan. LP3ES.

Creswell, J. W. (1998). Qualitative inquiry and research design: choosing among five traditions. Thousand Oaks: Sage.

Cutlip, S. M., Center, A. H.\& Broom, G. M. (2000). Effective public relations. New Jersey: Prentice Hall International.

Johnston, J. \& Zawawi, C. (2004). Public relations: theory and practice. Sydney: Ligare Book Printer.

Littlejohn, S. W. (1996). Theories of human communication. Belmont California: Wadsworth. 
Maxwell, J. A. (1996). Qualitative research design: an interactive approach. London: Sage Publications.

Moleong, L. J. (2000). Metodologi penelitian kualitatif. Bandung: Remaja Rosdakarya

Moustakas, C. (1994). Phenomenological research methods. USA: Sage.

Mulyana, D. (2001). Ilmu Komunikasi: suatu pengantar. Bandung: Remaja Rosdakarya
(2002). Metodologi penelitian kualitatif, paradigma baru Ilmu Komunikasi dan Ilmu Sosial lainnya. Bandung: Remaja Rosdakarya.

Nasution, S. (1996). Metode penelitian naturalistik kualitatif. Bandung: Tarsito.

Suprayogo, I. \& Tobroni. (2001). Metodologi penelitian sosial-agama. Bandung: Remaja Rosdakarya. 